Sohar, Paul. "Radnóti, Miklós. 2015. Eclogues and Other Poems (trans. Jack Roberts). Szeged: Americana e-Books. 88 pp." Hungarian Cultural Studies. e-Journal of the American Hungarian Educators Association, Volume 9 (2016): http://ahea.pitt.edu DOI: 10.5195/ahea.2016.242

\title{
Radnóti, Miklós. 2015. Eclogues and Other Poems (trans. Jack Roberts). Szeged: Americana e-Books. 88 pp.
}

\section{Reviewed by Paul Sohar, poet and translator}

Modern Hungarian poetry came into its own in the interwar years, in the 1920s through the 1940s, at a time when great political upheavals swept the world even as it was undergoing rapid industrialization and urbanization. The stylistic as well as political break with nineteenth century romanticism actually came with Endre Ady (1877-1919). Ady's symbolist style, derived from the French Decadent poets, put an end to the highfalutin tone of odes and congenial folk songs prevalent before his time, and his unaccustomed social criticism transformed the meaning of patriotism, investing it with tough love. His style did not work for anyone else, but it did open the way for the poets following him to start using everyday -- often meaning colloquial -language even in formal poetry. Inversions, archaic phrases, and dramatically strained word order were all thrown out of the window along with the romantic illusions of the nineteenth century; whereas jingoistic patriotic ballads and exhortations were left to second- and third-rate versifiers. The natural flow of the language was allowed to prevail. The only reason why formal poetry was not abandoned was the flexibility of Hungarian language, which can provide an almost infinite number of rhyme pairs, as it is one of the few modern languages that can accommodate the old Latin meter based on syllable length rather than on accent. Free verse was also pursued, but all the best poets of the interwar period wrote their most successful works in traditional forms, using rhyme and meter. Still, the old Latin form can be found only in a few skillfully crafted poems, including in the Eclogues of Miklós Radnóti (1909-1944), the subject of this review.

Ady's other legacy, meaning his social criticism, also entered into the poetry of the interwar years, but each poet handled it his own way; Attila József (1905-1937) unabashedly involved himself in politics on the side of the proletariat, the side where he was born, while others, like Mihály Babits (1883-1941), took a more philosophical stand; but more commonly the leading poets simply dissociated themselves from the values of the existing social structure and preferred to stand on the sidelines, bemoaning their isolation. Such an attitude is reflected in the poems of other interwar poets such as Dezső Kosztolányi (1885-1936), Lörinc Szabó (19001957), Jenő Dzsida (1907-1938), and Sándor Márai (1900-1989), among others. These poets presented more of a personal view from their own very private existence, keeping apart from society. Alienation, however, was not in Miklós Radnóti's nature, as he seemed to be in love with life; in his case alienation was forced upon him by the politics of his time. He came from a Jewish background, and in his last few years he suffered the indignities of discrimination as a Jew. He was conscripted into a labor battalion in World War II, served on the eastern front until he was discharged wounded, and after the German takeover of Hungary in the spring of 1944 he was pressed into a unit used for plain forced labor in Serbia and then marched westward as the Germans retreated. Finally, in an effort to save their own lives the guards got rid of the exhausted

$($ (c) $)$ EY

ULIS D-Sonfe
New articles in this journal are licensed under a Creative Commons Attribution 4.0 International License.

This journal is published by the University Library System of the University of Pittsburgh as part of its D-Scribe Digital Publishing Program and is cosponsored by the University of Pittsburgh Press 
Sohar, Paul. "Radnóti, Miklós. 2015. Eclogues and Other Poems (trans. Jack Roberts). Szeged: Americana e-Books. 88 pp." Hungarian Cultural Studies. e-Journal of the American Hungarian Educators Association, Volume 9 (2016): http://ahea.pitt.edu DOI: 10.5195/ahea.2016.242

among their laborer subordinates by shooting them, including Radnóti. His disinterment and the finding of his last poems in his pocket is by now a well-known story, and it made him an iconic figure representing the innocent victims of the Holocaust.

Beside Attila József Radnóti is the most often translated twentieth-century Hungarian poet, and deservedly so; the poems he wrote on the eve of and during the war illustrate the mood of the time not only with poetic skill but also with great subtlety and without predictable political rant. Therefore, it seems like a good idea to collect the most outstanding of these poems of Radnóti in one book, and that is exactly what Professor Jack Roberts of the New York State Saint Thomas Aquinas College did in this slim volume in which, he claims, he was the first one to put all the Eclogues together in an English edition. In addition, this collection contains all the favorites, including "Forced March" ('Erőltetett menet') and "Razglednicas" ('Razglednicák'), all of them very tragic and yet all of them full of vivid descriptions of the poet's surroundings, and all of them written in a language with a natural flow and within traditional forms, modern or classical. Rhyme and meter do not seem to act like constraints in Radóti's hands; instead, they almost spur the poet on and guide his unstoppable stream of thoughts and metaphors. It is a formidable task to reproduce this kind of modern, unstilted language within traditional forms, and it is only natural to say that any new translation volume is all about the translation, especially if the poet is well known and has already been translated umpteen times. It is only logical to ask, then: What is the justification for this addition to the already existing impressive list of former efforts to translate Radnóti?

In his introductory "Translator's Note" Roberts parries this question of the novelty of his new translation by making "no claims for the aesthetic value of these translations" while "striving for accuracy of diction and tone throughout" (i). What are we to make of that? Are we given a raw translation with good English diction? Or is it a raw translation that imitates Hungarian diction? And how about the accuracy of the translation itself? I can see the need for an accurate prose translation for an Anglophone Radnóti fan who, after reading the poems in different versions that attempted to create an English version more or less in the original form, wants to see the content in plain, prosaic English. On that account, though, the critic may feel empowered to intervene between the reader and the translator; because in that case it is no longer a question of aesthetics but one of textual accuracy. Roberts does not name the source of a raw translation; therefore, we can safely assume he has a good command of the Hungarian language, and I have seen native speakers of Hungarian give widely different interpretations of a Hungarian poetical text. His sketchy biography mentions a short stint as a lecturer at the University of Szeged in Hungary, where he continues to visit for occasional lectures and to have his books published.

Indeed, there is no form to speak of in Jack Roberts's rendition of these poems, because, as he says of his work, it is but a prose translation cast in stanzas that look like the original but with nary a rhyme or meter in sight. Thus the famous hexameters of the Eclogues fall flat and the only concession to poetry is an occasional old-fashioned fractured sentence structure, or an inversion, which is supposedly intended to indicate poetic diction. Inevitably the question arises: If the translator did not strive for aesthetic value, why did he not give a plain and faithful prose rendition? If showcasing the Eclogues consecutively together was Roberts's main purpose he could have served it better by using some of the formal translations already abundantly available. What we have now is an unsuccessful compromise, a fractured prose translation that obscures 
Sohar, Paul. "Radnóti, Miklós. 2015. Eclogues and Other Poems (trans. Jack Roberts). Szeged: Americana e-Books. 88 pp." Hungarian Cultural Studies. e-Journal of the American Hungarian Educators Association, Volume 9 (2016): http://ahea.pitt.edu DOI: 10.5195/ahea.2016.242

the meaning of the original. Worse than that, it negates the best part of this poetry in Hungarian, meaning the natural flow of an everyday talking voice elevated to the level of oratory by the unobtrusive use of traditional forms. The best thing about the book is the inclusion of the original text, which makes the evaluation easier. But that is not enough; it also helps to have a few earlier translations at hand that inevitably clamor for attention and comparison (e.g., see the latest: Miklós Radnóti, The Complete Poetry in Hungarian and English, trans. Gabor Barabas.

Jefferson, NC: McFarland and Company Inc., 2014).

Unfortunately, the translation is clumsy and choppy from the very beginning. Take, for example, the last line of "First Eclogue," an almost painfully beautiful hexameter in the original and a veritable tongue twister in this translation: "... sunset's butterfly's aflutter, and silver's spun of spinning wings" (7); [alkonyi lepke lebeg már s pergeti szárnya ezüstjét.'] (5). A plain raw translation of this line would be: "... a twilight moth is already afloat, fluttering the silver of its wings." Other examples of inelegant, infelicitous phrasing can be selected almost at random. Let us see the first two lines from "Second Eclogue":

We flew so far last night, I had to laugh from rage;

droning, their fighters, raining fire, fell on us

like swarming bees... (11).

[Jó messzi jártunk éjjel, dühömben már nevettem, méhrajként zümmögött a sok vadász felettem] (9).

Again, a plain raw translation of these lines would be:

Never have we wandered off so far, fury made me laugh, a myriad fighter planes were buzzing over me like a swarm of bees.

The musicality of the original is so enrapturing, and it sets the bar so high for a translator, that perhaps there is no point in tackling the task, which is why so many poets/translators have tried. The secret of the poem's music lies in an almost unique Hungarian form of poetry, meaning classical meter combined with rhyme and a judicious amount of alliteration.

Here is one more challenging poem where Roberts's "accuracy of diction" (i) badly failed: the first two lines from "Forced March" ('Eröltetett menet') amply illustrate the way he chops up lines and changes images for no discernible gain in style or information:

Earth-thick, he earthward stumbles, staggers up, forward lurches, hobbling extravagant pain stirs feet, spurs hard the haunches (69).

[Bolond, ki földre rogyván fölkél és újra lépked, $s$ vándorló fájdalomként mozdít bokát és térdet] (68) 
Sohar, Paul. "Radnóti, Miklós. 2015. Eclogues and Other Poems (trans. Jack Roberts). Szeged: Americana e-Books. 88 pp." Hungarian Cultural Studies. e-Journal of the American Hungarian Educators Association, Volume 9 (2016): http://ahea.pitt.edu DOI: 10.5195/ahea.2016.242

A raw translation of these lines could be:

He's a madman who after collapsing on the ground gets up and takes another step, and it's a wandering ache when he forces ankles and knees.

As for a poetic translation of the same lines, one might consider Peter Zollman's rendition, published in an anthology entitled In Quest of the Miracle Stag - Poetry of Hungary and edited by Adam Makkai (Chicago and Budapest: Atlantis Centaur and Corvina, 1996).

He's mad, who, lying half dead gets up to march again, a walking heap of torment bends ankles, knees and brain, (719).

Unfortunately, Zollman adds an extra word (brain) straining for a rhyme -- and a weak one at that! -- but at least he keeps to the original text. The extra word? As an editor I would red-pencil it and send it back for correction, but as a critic I can only say it's still better than Roberts's work.

This is a good place to bring up the issue of textual accuracy. Later in this poem it turns out that the hope of reuniting with the wife is what gives the forced laborer the strength to go on:

....and Fanni blondely loiters in red hedgerow shade, shadow languidly penciled in languorous morning perhaps she's loitering still! the moon is so round today! (69).

[és Fanni várna szökén a röt sövény elött, s árnyékot irna lassan a lassú délelött, de hisz lehet talán még! a hold ma oly kerek!] (68).

The raw translation of this poem is:

....and Fanni is still blond, still waiting by the reddish hedgerow, the slow morning slowly scrawling a shadow, -but perhaps it's still possible! the moon is so round today!

In addition, the following poetic translation by Peter Zollman, from the same Miracle Stag anthology, offers a very different treatment of these same lines:

....and Fanni's blond hair greeted before the tawny hedge, and shadows slowly doodled a lazy, lacey sketch, -but wait, there may be hope yet! the moon is strangely large! (719).

Zollman takes poetic license for the sake of form and still fails to realize the poetry of the original, but he would never make the mistake of using such a jarring word as "loiter" to describe the poet's agitated, expectant wife, because for contemporary readers this word immediately conjures up the image of a sign posted in the parking lot of a convenience store: "No Loitering!" 
Sohar, Paul. "Radnóti, Miklós. 2015. Eclogues and Other Poems (trans. Jack Roberts). Szeged: Americana e-Books. 88 pp." Hungarian Cultural Studies. e-Journal of the American Hungarian Educators Association, Volume 9 (2016): http://ahea.pitt.edu DOI: 10.5195/ahea.2016.242

It is hard to imagine why a native speaker of English would mar a serene scene with that word; a poetic expression of longing surely calls for a picture of the lady standing by the hedge in front of the family home; there she is waiting for her beloved husband with as much longing as the imprisoned husband feels. He is pining away for her, hoping she feels the same way about him. That is definitely not loitering. Is this a poor word choice or a misreading of the text and its situational context?

One could ask the same question in connection with the translation of the word "ös" in "Eighth Eclogue," line 10 (32). As a noun this word means "ancestor," but as an adjective it means "ancient," and it is in the latter sense that Radnóti used it in his Eclogue. All the other translators got it right, except Roberts, whose misreading causes the misreading of the whole poem as he makes of the Prophet a latter-day descendant of the ancient Prophets, whereas in the original the poet speaks in his imagination over the millennia directly to Biblical Prophet Nahum. Finally, all this should be obvious from the use of the second person singular rather than the third person referred to in the translation.

Roberts:

Of your furious ancestor I know, what he wrote endures (35).

[Ismerem ös dühödet, mert fennmaradott, amit irtál] (32).

Raw Translation:

I'm acquainted with your ancient rage, because what you wrote is still extant.

Zollman:

I am acquainted with all your words, your Book is alive still (Miracle Stag, 717).

These two examples of misreading and mistranslating of Radnóti's poetry are perhaps the most egregious but by no means unique; the book is riddled with them, sometimes not only marring the tone of the poem but entirely distorting the content. Radnóti deserves better. The Biblical majesty of the language imparts a timeless, universal mood to this Eclogue (the Eighth, dated Aug 23, 1944, Serbian mountains), the last in the cycle chronicling the poet's increasing alarm over the war, starting in 1938 and full of foreboding at the beginning, then gathering more and more despair, until the end when the poet tries to find a larger, perhaps a divine, purpose to the tragedy playing out around him and torturing him personally.

But it was only two months later, in October 1944, that Radnóti began to worry about his own surviving this ordeal. This anxiety is expressed in his last "Razglednica" poem, No. 4, a poem that has probably seen more translation than any other Hungarian work of poetry. It foretells in shocking detail the way the poet was to die only weeks later; it would be a mistake not to recall it now to memory:

Fell down beside him, the body turned over, taut as a string near breaking, sprang up. Neck-shot. "Just such an end you'll make." Whispered to myself, "Just lie still, steady." 
Sohar, Paul. "Radnóti, Miklós. 2015. Eclogues and Other Poems (trans. Jack Roberts). Szeged: Americana e-Books. 88 pp." Hungarian Cultural Studies. e-Journal of the American Hungarian Educators Association, Volume 9 (2016): http://ahea.pitt.edu DOI: 10.5195/ahea.2016.242

Now death flowers of patience.

"Der springt noch auf," sounds above me.

Blood, mixed with mud, dries on my ear (73).

[Mellézuhantam, átfordult a teste

s feszes volt már, mint húr, ha pattan.

Tarkólövés. - Így végzed hát te is, -

súgtam magamnak, - csak feküdj nyugodtan.

Halált virágzik most a türelem. -

Der springt noch auf, - hangzott fölöttem.

Sárral kevert vér száradt fülemen]

Szentkirályszabadja, 1944. október 31 (71).

In the last two lines of this poem Roberts shifts to the present tense, probably for dramatic effect, but a translator is not authorized to make such changes for no particular reason. As for the content and its meaning, the corpse does not spring up, but is rather stiff like a string that is about to snap. The original is indeed very terse, the lines are dense and difficult to elucidate, but that is exactly what a good translator should do before making poetry out of it in the target language; the translator should write out the meaning of the source material in plain language in order to be sure to have the content clearly in mind and be able to visualize the scene and its imagery.

Accuracy of content is at least as important as the "accuracy of diction and tone," (i) and not much of the latter is in evidence here either. Both these kinds of accuracy can be found in Zollman's translation:

I tumbled next to him, his body turned and tightened like a string about to go, shot in the head. - This is how you will end, I breathed, - just lie rigid from top to toe. Now death blossoms where patience perseveres. - "Der springt noch auf!" - sounded above me. A sludge of gory mud clotted my ears (Miracle Stag, 73).

Perhaps poetically not better but even closer to the original is this reviewer's own version (Paul Sohar, Homing Poems. Manasquan NJ: Iniquity Press, 2005):

I hit the ground beside his corpse; it flipped, already as stiff as a string about to break. Shot in the back of the head. "You'll be next," I told myself, "just lie still without a quake." "Only death can flower now from self-control." "Der springt noch auf," someone barked above.

On my ear dry blood and mud closed up the hole (p.130). 
Sohar, Paul. "Radnóti, Miklós. 2015. Eclogues and Other Poems (trans. Jack Roberts). Szeged: Americana e-Books. 88 pp." Hungarian Cultural Studies. e-Journal of the American Hungarian Educators Association, Volume 9 (2016): http://ahea.pitt.edu DOI: 10.5195/ahea.2016.242

The gigantic anthology of Hungarian poetry cited above showcases no less than four translation versions of this poem, perhaps in the hope that together they may approximate the tone of the original Hungarian poem and convey its spirit, the last breath of the poet. Perhaps looking at multiple versions is the only way to close in on the original. But still, the mournful music embedded in the closing rhyme scheme of the relentless pentameters (türelem/ fülemen, lit. patience/on my ear) so far eluded every translator's efforts. It is also interesting to note the contradiction in the poem: the poet warns himself to lie low and be patient even though he suspects it is of no use, as death is inevitable one way or other. At the same time, the eastern front was rapidly closing in, and there was hope for liberation; that is, if he could hold out only a little longer. The poet does not mention the possibility of trying to run away from the column of prisoners, but that is implied in his being torn between hope and acquiescence to fate. Or is the poet contemplating falling down and playing dead by his friend's corpse in the hope of being left behind and free to flee to safety? If so, then he is pessimistic about the outcome: his hope for such an escape is dashed by the -- supposedly -- Nazi guard's remark "he might get up yet" and therefore he envisions himself also shot in the back of the head with blood trickling down on his muddy ears. One way or another, there's no chance of escape.

Interestingly, all the other "Razglednica"s are in the present tense except for this, the last one, in which the poet could foresees his end and describes it as already a fact, past history. The translator is free to speculate but cannot impose conjectures on the text; at least in this one instance no such mistake was committed by any of the numerous translators; they all left the poem as vague as the poet intended. In addition, the German quote is the kind of small detail that adds authenticity to a poem based on personal experience; it is the particular that can elevate a poem to the level of the universal. Radnóti was never satisfied with bland generalities, yet he was able to weave vivid images of reality into his poetic lines

The one indisputable virtue of this small collection is that in a slim volume it brings together the poet's most important and most unique poems, the ones that combine his personal reaction to the drama of World War II (which, very perceptibly, started for him with the Spanish Civil War in 1936) and his meditations on those events in a unique blend of modern, everyday language poured into the formal mold. The addition of four love poems to his wife does not dilute the generally somber mood of the book but enliven it with counterpoints; to the poet his wife symbolized not only love but life and hope for normalcy, which is why she is always present in his consciousness even in the most dire situations. Radnóti gives a glimpse of the Holocaust from a unique vantage point of an almost-survivor who managed to record his story almost to the end, which makes his fate all the more tragic and his testimony of his own experience of the Holocaust close to complete. Another heart-wrenching part of his story is his undying optimism and trust in justice. Why did he answer the recall into service in 1944 when the end was so near? Instead of going into hiding he got baptized into Roman Catholic religion and went back into service like an innocent sacrificial lamb. Comparison with György Faludy (1910-2006), his exact contemporary, is inevitable. The latter, after a brief service in the Hungarian army, escaped the country and went on to live an adventurous life until the age of ninety-six. As a Jew he could have shared the fate of his fellow poet. Was he a better judge of politics and human nature or just lucky? 
Sohar, Paul. "Radnóti, Miklós. 2015. Eclogues and Other Poems (trans. Jack Roberts). Szeged: Americana e-Books. 88 pp." Hungarian Cultural Studies. e-Journal of the American Hungarian Educators Association, Volume 9 (2016): http://ahea.pitt.edu DOI: 10.5195/ahea.2016.242

By now Radnóti is an almost legendary figure; his life and works will forever intrigue poetry lovers, and no amount of books about him or translations of his poetry is ever too many. Jack Roberts's new volume, its faults notwithstanding, is a welcome addition to the already existing corpus of Radnóti translations. Its concentration on the war theme limits its size to the poems truly unique to this singular Hungarian poet and may recommend itself to the attention of Anglophone readers not yet familiar with Miklós Radnóti. The inclusion of the original Hungarian text and the date of each poem make it a handy reference work to have. 